○

OPEN ACCESS

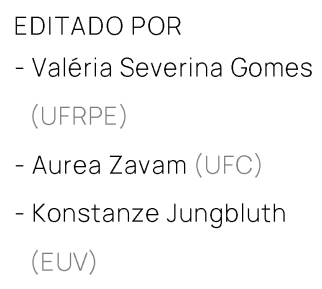

\title{
Os modos tradicionais de dizer dos séculos XIX e XX: uma análise de cartas pessoais de pernambucanos
}

\author{
Elizabhett Christina Cavalcante da COSTA (D) \\ Universidade Federal de Pernambuco (UFPE) \\ Claudia Roberta Tavares SILVA (D) \\ Universidade Federal Rural de Pernambuco (UFRPE) \\ RESUMO
}

Ao investigarmos os diferentes modos tradicionais de dizer presentes em 80 cartas pessoais (subgêneros cartas de amigo e cartas de família) de pernambucanos do século XIX e XX, objetivamos verificar quais marcas composicionais estão presentes nas missivas e como as formas recorrentes de dizer contribuem para uma maior ou menor implicação emocional das expressões e, também, o que isso, consequentemente, nos traz de evidência acerca do grau de proximidade/distância comunicativa a partir da observação das relações de poder (hierárquicas) ou igualitárias presentes (BROWN; GILMAN, 1960). Para isso, adotamos o modelo de abordagem das Tradições Discursivas (TD) (KOCH; OESTERREICHER; 2006; KABATEK, 2006), a fim de percebermos quais marcas pragmático-discursivas são evocadas no gênero carta pessoal. Os resultados nos mostram que o uso de expressões recorrentes da carta pessoal se apresentou nos dois subgêneros da missiva e nos dois séculos e que esse uso oscila e é atualizado de missivista para missivista, dependendo de com quem se fala, do objetivo da carta e da assimetria ou simetria no relacionamento construído entre os correspondentes.

\section{ABSTRACT}

This paper aims to analyze the different traditional forms of discourse in 80 personal letters (subgenres friend and family letters) of Pernambuco from 


\section{REVISTA DA ABRALIN}

19th and 20th century. Thus, we intend to understand which compositional marks are present in the missives and how the recurring forms of speech contribute more or less to the emotional implications of the expressions and, consequently, if that brings us evidence about the degree of communicative proximity/distance. Therefore, we intend to observe the hierarchical or egalitarian relations that are in the linguistic forms in the missives of Pernambuco (BROWN; GILMAN, 1960). For this, we adopt the Discursive Traditions (TD) model (KOCH; OESTERREICHER; 2006; KABATEK, 2006), in order to understand which pragmatic-discursive brands are evoked in the personal letter of the subgenres: friend and family letters. The results show that the use of recurrent expressions of the personal letter are manifested in these subgenres and in two centuries. Futhermore, we obtained the result that the usage varies and is updated by the letter's writer and depends on who you are talking to, the goals of the letter and the asymmetry or symmetry of the relationship between the interlocutors.

\section{PALAVRAS-CHAVE}

Gênero textual. Carta pessoal. Tradição discursiva. Marcas composicionais.

\section{KEYWORDS}

Textual Genre. Personal Letter. Discursive Tradition. Compositional marks.

\section{Introdução}

Neste estudo, optamos por analisar 80 cartas pessoais de pernambucanos dos séculos XIX e XX nos seguintes subgêneros: cartas de amigo e cartas de família, tendo como objetivo geral abordar os modos tradicionais de dizer - que correspondem às Tradições Discursivas (TD), considerando a composicionalidade do gênero carta pessoal e expressões linguísticas que possam evocar usos tradicionais de dizer.

Acreditamos que as marcas de TD poderão revelar, nas relações de intimidade entre os correspondentes, certas preferências por elementos composicionais de maior expressividade emocional e isso estará presente em elementos como saudação, captação da benevolência, pedido, despedida e, até mesmo, a assinatura. Ademais, verificaremos possíveis modos de dizer tradicionais e a implicação emocional das expressões a partir do tipo de relação que os interlocutores possuem, sejam hierárquicas ou igualitárias. 


\section{REVISTA DA ABRALIN}

Sob o viés teórico da historicidade da língua e do texto (KOCH; OESTERREICHER, 2006; KABATEK, 2006), aqui adotado, acreditamos que os textos, falados ou escritos, que produzimos são tradicionalmente usados e atualizados na história, assim como ocorre com a língua. O uso da língua é, portanto, uma tradição histórica e, por sua vez, evoca tradições no falar. Para Kabatek (2006), o texto é um acontecimento histórico, arquivado na memória cultural de uma determinada comunidade, que é atualizado e forma arquétipos tradicionais. Dessa forma, é evocado através de repetições na forma ou no conteúdo. É a repetição de um texto atual com um anterior que sustenta o conceito de TD, pois é esse movimento que compõe o texto em toda a sua historicidade. Portanto, é nesse caminho que a oralidade se conduz pela história e, assim, podemos verificar modos tradicionais de dizer na carta pessoal em que há proximidade com a oralidade, entendida por Marcuschi (2008) como uma modalidade discursiva, tal como o é a escrita.

Ademais, assumimos com Marcuschi (2008, p. 51) que língua é "um conjunto de práticas sociais e cognitivas historicamente situadas" e o gênero, uma prática social e textual-discursiva, que não pode ser compreendido afastado do texto (objeto empírico) e do discurso (objeto do dizer).

Longhin-Tomazi (2014, p. 22), por sua vez, reafirma que "é a relação de tradição entre os textos que torna legítimo o conceito de TD” e, portanto, é a repetição juntamente com a atualização que tem definido a historicidade e tradicionalidade dos textos. Isso contribui para que, em um determinado evento comunicativo, haja um encontro entre um texto inédito que se relaciona com outro texto enunciado anteriormente, repetindo e evocando tradições (KABATEK, 1996, 2006). Tal compreensão sobre o texto e sua historicidade é fulcral para a compreensão do gênero textual-discursivo carta pessoal, com o qual analisaremos as TD tanto nos aspectos composicionais da estrutura do gênero (como vocativo ou saudação, captação da benevolência, despedida) quanto nos a spectos linguístico-discursivos, nos modos tradicionais de dizer (LONGHIN-THOMAZI, 2014).

Estando, portanto, este estudo embasado na perspectiva teórica das TD, vale dizermos que o corpus é constituído por 80 cartas dos séculos XIX e XX de remetentes pernambucanos ilustres e não ilustres, estando subdivididas nos subgêneros: cartas de amigo e cartas de família, conforme encontram-se distribuídas no quadro abaixo:

\begin{tabular}{|c|c|c|c|c|}
\hline \multirow{2}{*}{ Subgênero } & \multicolumn{4}{|c|}{ Quantitativo por século } \\
\cline { 2 - 5 } & $\begin{array}{c}2^{\text {a }} \text { metade do século XIX } \\
\mathbf{( 1 9 5 1 - 1 9 0 0 )}\end{array}$ & $\begin{array}{c}\mathbf{1}^{\mathbf{a}} \text { metade do século XX } \\
\mathbf{( 1 9 0 1} \text { a 1950) }\end{array}$ & $\begin{array}{c}\mathbf{2}^{\mathbf{a}} \text { metade do século XX } \\
\mathbf{( 1 9 5 1 \text { a 2000) }}\end{array}$ & Total \\
\hline Amigo & 11 & 6 & 4 & $\mathbf{2 1}$ \\
\hline Família & 5 & 50 & 4 & $\mathbf{5 9}$ \\
\hline TOTAL & 16 & 56 & 8 & $\mathbf{8 0}$ \\
\hline
\end{tabular}

QUADRO 1 - Quantitativo geral do corpus por século e por subgênero da carta pessoal 


\section{REVISTA DA ABRALIN}

Todas as cartas foram coletadas após a aprovação do Comitê de Ética em Pesquisa (CEP) da Universidade Federal de Pernambuco (UFPE) (CCAA: N. ${ }^{\circ}$ 2.590379) e encontram-se acessíveis nos acervos da Fundação Joaquim Nabuco (Fundaj-PE), do Arquivo Público Estadual Jordão Emerenciano (APEJEPE) e do Projeto Para a História do Português Brasileiro desenvolvido em Pernambuco (PHPB-PE). Essas cartas foram registradas fotograficamente nos acervos e transcritas segundo as normas de transcrição semidiplomática baseadas na discriminação dos símbolos de ordem filológica realizada por Guedes e Berlinck (2000, p. 12) e adotadas pelo grupo de investigadores que integram o PHPB ${ }^{1}$.

Justificamos a escolha pela carta pessoal enquanto corpus histórico, pois, além de possuir proximidade com a oralidade, através dela temos acesso à língua de outros tempos, conhecemos o missivista e suas escolhas linguísticas, podemos construir o perfil social, saber o local, a data e, também, os modos tradicionais de dizer (ANDRADE; GOMES, 2018). Essa linha de pensamento vai na direção de Pessoa (2002, p. 197) ao afirmar que as cartas são um "dos gêneros mais importantes da história das línguas [...]. Hoje tem sido o gênero preferido por muitos para estudos diacrônicos da língua pela suposta proximidade com o oral".

Ao longo da análise, foram adotados os métodos histórico e comparativo (LAKATOS; MARCONI, 2003): o primeiro, para compreendermos os modos tradicionais de dizer e o perfil social dos missivistas e do contexto de produção da carta em diferentes séculos e o segundo, para estabelecermos comparação entre os dados dos séculos XIX e XX e entre os subgêneros em análise. Para tanto, este artigo encontra-se assim estruturado: na seção 2, discutiremos o gênero carta pessoal sob o viés das TD; na seção 3, analisaremos as TD recorrentes na composição das cartas de pernambucanos, e, por fim, apresentaremos as considerações finais, reunindo os principais resultados encontrados.

\section{Sobre o gênero carta}

Ao considerarmos a carta pessoal como um dos gêneros fundamentais para o estudo da história das línguas e dos textos, é preciso termos em mente que os gêneros, assim como a língua, também se modificam ao longo do tempo. Através da carta, podemos estudar as transformações da língua, a função desse gênero em diferentes momentos históricos e, também, a contribuição para a formação de outros gêneros (PESSOA, 2002).

A carta pessoal, denominada na Retórica de epistola familiaris, conglomera uma série de realizações com propósitos comunicativos distintos, "desde o desejo de expressar amizade, o de falar

\footnotetext{
${ }^{1}$ O coordenador geral do PHPB, no período de 1998 a julho de 2019, foi o Prof. Dr. Ataliba Teixeira de Castilho (USP/ Unicamp). Atualmente, ocupa esse cargo o Prof. Dr. Sandro Marengo (UFS/UEFS). No que se refere à equipe regional do PHPB em Pernambuco, tem sido coordenada atualmente pelo Prof. Dr. Cleber Alves de Ataíde (UFRPE) em substituição à Profa. Dra. Valéria Severina Gomes (UFRPE).
} 


\section{REVISTA DA ABRALIN}

sobre religião, o de fazer fofoca sobre a vida alheia, o de dar notícias sobre a família até o de declarar amor de forma íntima" (CASTILHO DA COSTA, 2012, p. 145).

A partir da compreensão de que "o gênero carta pessoal não é totalmente livre", Castilho da Costa (2012, p. 146-151) afirma ser um gênero atravessado por um conjunto de tradições que determinam as escolhas linguísticas dos missivistas. A autora ressalta a carta como um sermo absentis ad absentem, ou seja, uma conversa entre duas pessoas ausentes. Conforme Castilho da Costa (2012, p. 151), boa parte das cartas pessoais obedece às tradições que remontam à Antiga Retórica grega e romana por estas serem divididas basicamente em cinco partes:

a) Salutatio $=>$ diz respeito à saudação ${ }^{2}$;

b) Captatio benevolentiae $=>$ refere-se à captação da benevolência do interlocutor;

c) Narratio => contém informações sobre um estado das coisas, é o desenvolvimento da carta;

d) Petitio => refere-se ao pedido;

e) Peroratio $=>$ corresponde à conclusão (seguida da assinatura) e, também, poderá conter uma recapitulatio, um resumo do que já foi mencionado e, até mesmo, um apelo às emoções (solidariedade, indignação, entre outros).

São essas partes da carta pessoal que abarcam os modos tradicionais do dizer que vão desde um "bom dia!", com a finalidade comunicativa de saudar o interlocutor (ou interlocutores) até expressões formulaicas de despedida e assinatura, com a finalidade de despedir-se e concluir a carta. Nesse sentido, as expressões formulaicas na estrutura composicional da carta interligam-se diretamente tanto ao propósito ou finalidade comunicativa que o remetente quer atingir quanto ao grau de intimidade estabelecido entre os missivistas. Podemos perceber o grau de intimidade, a partir, sobretudo, da implicação emocional estabelecida na expressividade ao empregar determinados elementos linguístico-discursivos (CASTILHO DA COSTA, 2012). Esse grau de intimidade - que se refere à distância entre os interlocutores -, portanto, irá estabelecer como será a constituição composicional de uma carta. Corroborando essa afirmação, Bazerman (2006, p. 87) defende que a carta, enquanto meio de comunicação que serve para aproximar distâncias entre os interlocutores,

fornece um espaço transacional aberto, que pode ser especificado, definido e regularizado de muitas maneiras diferentes. As relações e transações em curso são mostradas para o leitor e o escritor diretamente através das saudações, das assinaturas e dos conteúdos da carta. Além do mais, cartas podem descrever e comentar - frequentemente de modo explícito - a relação entre os indivíduos e a natureza da transação corrente [...] a organização e as transações podem alcançar distâncias maiores, como também os laços sociais entre os indivíduos podem ser reforçados e até criados através de relações indiretas com outras pessoas.

\footnotetext{
${ }^{2}$ Conforme Castilho da Costa (2012, p. 151), a saudação e a captação da benevolência, juntas, constituem o exordium e, portanto, esse esquema pode, por vezes, aparecer de modo simplificado na carta pessoal. Sendo assim, a missiva apresentaria tais partes: salutatio, exordium, narratio e conclusio (despedida, data e assinatura (subscriptio)).
} 


\section{REVISTA DA ABRALIN}

Ademais, a carta pessoal é um gênero que abarca outros subgêneros e, portanto, evoca tradições de acordo com a função discursiva em que está inserida e isso a identificará como sendo uma carta de amor (trocada entre namorados, amantes, noivos, casados), uma carta de amigo (trocada entre amigos e colegas) e uma carta de família (trocada entre familiares). Esses três subgêneros correlacionam-se com os tipos de relações estabelecidas entre os interlocutores (SOUZA, 2012; SILVA, 2018).

Nas palavras de Silva (2018), a carta é um hipergênero por englobar outros gêneros discursivos (como a carta comercial e a carta pessoal) que cumprem a função de acordo com características específicas e a partir da finalidade comunicativa de cada gênero, e é isso que permite a comunicação ser intermediada entre os interlocutores. No tocante a essa comunicação, Souza (2012) ressalta que são diversos os assuntos trocados entre os missivistas, desde notícias de familiares e de amigos distantes, reclamações, informações, agradecimentos, pedidos, intimação, até mesmo, correspondências enviadas a jornais e revistas. Sendo assim, a carta, cumprindo suas diferentes funções, transita em diferentes esferas de atividades, como em relações pessoais, situações públicas, etc. (SOUZA, 2012, p. 59). Além disso, sua estrutura composicional pode-nos revelar, por exemplo, a relação mantida entre os correspondentes no estabelecimento amizade/ intimidade (CASTILHO DA COSTA, 2012) em uma relação de proximidade comunicativa (KOCH; OESTERREICHER, 2006).

A fim de tratarmos da relação de proximidade comunicativa, recorremos à Teoria do Poder \& Solidariedade, de Brown e Gilman (1960). Nessa teoria, na relação de Poder, assimétrica, há a hierarquização das relações, sendo assim, elegem-se certas formas de tratamento diferentes, nãorecíprocas na comunicação que é estabelecida entre os interlocutores. No tocante ao parâmetro da Solidariedade, relaciona-se com o nível igualitário das relações interpessoais e da hierarquia social. Assim sendo, o Tu remete ao tratamento igualitário, por exemplo, das relações de amizade e é nesse sentido que "[...] se outorga o uso mútuo do TU (recíproco ou igualitário), logo o uso simétrico de TU configuraria intimidade (sentimento de solidariedade entre os participantes da situação comunicativa)" (GOMES; LOPES, 2016, p. 141). Em contrapartida, a forma Você, por ter um caráter mais cerimonioso, estaria interligada com as relações hierárquicas ou de poder, como bem verificam Brown e Gilman (1960). Entretanto, conforme Gomes e Lopes (2016), o Você, no português brasileiro (PB), na virada do século XIX para o século XX, já ocupa e concorre com o Tu o lugar de segunda pessoa do discurso; por isso, ora conserva o caráter cerimonioso, respeitoso, em relacionamentos assimétricos e, ora, juntamente com o Tu, é usado nos relacionamentos de intimidade, a fim de estabelecer um tratamento igualitário, como de amizade ou amor. Com base nisso, é importante termos em mente as seguintes caracterizações de relação apresentadas por Gomes e Lopes (2016, p.141-142):

\footnotetext{
I. Relação simétrica: dizem respeito às relações entre amigos que constituem uma relação de igualdade. II. Relação assimétrica: relação hierárquica entre os interlocutores. a) assimétrica descendente: são as relações estabelecidas de superior para inferior, como de pai para filho, de mãe para filho. b) assimétrica ascendente: são as relações estabelecidas de inferior para superior, de filho para o pai ou de filho para a mãe. III. Relação simétrico-solidária: relações íntimas e amorosas estabelecidas entre um casal (GOMES E LOPES, 2016, p.141-142).
} 


\section{REVISTA DA ABRALIN}

Através do olhar para as peculiaridades da composição estrutural da carta pessoal, para os tipos de relações interpessoais e para o que conseguimos mapear do perfil social dos missivistas, esperamos, portanto, que esses dados extralinguísticos evidenciem as TD presentes no gênero carta pessoal e quais são os modos tradicionais de dizer. Para tanto, assumimos neste artigo que a carta pessoal é a "[...] comunicação eminentemente pessoal, uma correspondência que efetiva um contato privado e, quase sempre, constante, entre indivíduos - familiares e amigos íntimos - que mantêm entre si um relacionamento estreito" (NOVAES, 2006 apud SOUZA, 2012, p. 59). Essa carta, enquanto gênero discursivo, é marcada pela espontaneidade devido, sobretudo, à relação de intimidade estabelecida entre os missivistas e à tentativa de aproximação entre "os distantes".

\section{Compreendendo as Tradições Discursivas em cartas pessoais de pernambucanos}

Sabendo-se que a historicidade do texto se constrói através de textos ditos e escritos arquivados na mente de uma comunidade, consideramos a repetição de elementos linguísticos tradicionais (seja na forma ou no conteúdo) como crucial para garantir a historicidade de modelos linguísticos orais e escritos. Por isso, no tocante às 80 cartas pessoais, observamos que a maioria das missivas possuíam um formato tradicional que remonta à Antiga Retórica. Como podemos observar, na carta latina de Cícero $^{3}$, a seguir, existem algumas características composicionais do gênero carta pessoal que alcançaram os séculos XIX e XX das cartas de pernambucanos. Nessa carta, Pessoa (2018) atenta para a importância da marca de pessoa verbal, haja vista que, na carta pessoal, as pessoas do discurso assumem seus papéis na enunciação, havendo um jogo de alternância (seja eu/tu ou nós/vós). Além disso, há presença da saudação, captação da benevolência, cobrança para o interlocutor enviar mais missivas e, por fim, expressões formulaicas de despedida:

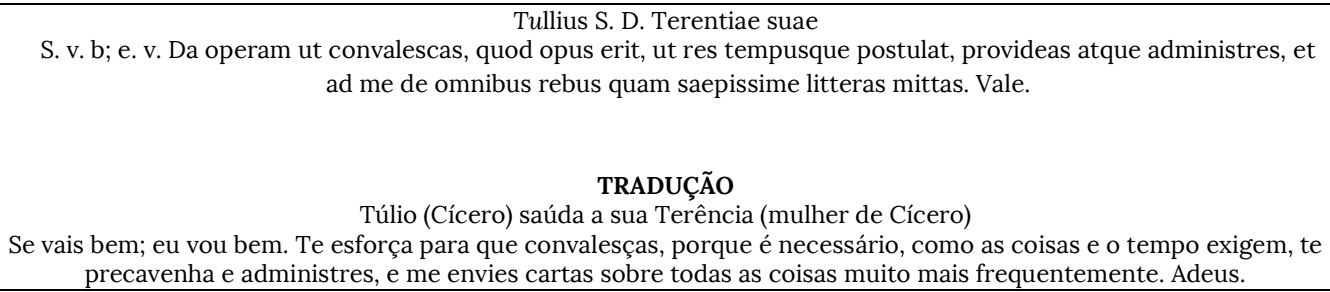

\footnotetext{
${ }^{3}$ Traduções livres feitas em 2018 pelo professor de História da Língua e Latim da UFPE, Prof. Dr. Marlos de Barros Pessoa, de trechos retirados das apostilas de Latim I e II.
} 


\title{
REVISTA DA ABRALIN
}

Segundo Pessoa (2018, p. 1-2), marcas do gênero carta pessoal são encontradas no quadro 2, a saber:

\begin{abstract}
I. Textualidade: a. no alto da missiva, há a pessoa que escreve e depois aquela a quem se escreve; $\mathbf{b}$. aparecem abreviaturas (S., S. D., etc.) que expressam o vocativo; c. aparecem outras abreviaturas (s. v. b., e.v.), que expressam saudação; d. o corpo do texto; e. a despedida (vale). II. Fórmulas: a. Em "Tullius S. D. Terentiae suae", temos S. D. como abreviaturas de "salutem dicit" (salutem acusativo de dicit) e "Terentiae suae" (dativo) = Túlio saúda sua Terência; b. Na saudação, temos a abreviatura "s. v. b; e. v." (si vales bene, ego valeo) = se estás bem, eu estou bem). Valeo/valere = estar bem de saúde; c. Na despedida, temos o "vale" (adeus); III. Formais verbais: a. Imperativo presente: uso do imperativo "Da", do verbo "do" (dare); b. $2^{\text {a }}$ pessoa do presente do subjuntivo: "[...] as formas do subjuntivo presente (PS) precedidas da conjunção ut: convalescas, provideas, administres, mittas. Como Túlio Cicero escreve para a filha, é claro que ele usa a $2^{a}$. pessoa singular, aquela com quem se fala. Marca -s [....]" (PESSOA, 2018, p. 1-2).
\end{abstract}

A ação de cobrar mais cartas, de saudar, de captar a benevolência e de se despedir utilizandose de expressões formulaicas é constantemente empregada nas cartas dos missivistas pernambucanos dos séculos XIX e XX, como veremos ao longo da análise. Para além dessas questões, os assuntos das missivas englobam notícias sobre si e outros, assuntos políticos, acontecimentos importantes e recomendações. Também são recorrentes esses assuntos nas cartas de Cícero e os próprios modos de dizer tradicionais, como o pedido como voto de amizade, mostrar ser íntimo da pessoa recomendada ao amigo interlocutor; além de haver um emolduramento da missiva com expressões formulaicas de vocativo, saudação, despedida e, por vezes, assinatura.

Conforme será visto nas próximas subseções, o formato tradicional da composição da carta é encontrado nas cartas de amigo e de família e está inserido em um conjunto de tradições internas ao gênero. Entretanto, as cartas de amigo do século XIX e XX que têm como assunto convite, negócios, breves relatos sobre política ou viagem, não seguem esse formato. Segundo Costa, Silva e Gomes (2018), essa "instabilidade" apresenta-se em algumas cartas por serem curtas e com uma finalidade muito específica, quando os correspondentes passam a enfocar na passagem de mensagens rápidas. Isso corrobora o que defende Bakhtin (2003, p. 279), uma vez que a forma e o conteúdo dos gêneros do discurso, por estarem inseridos em práticas sociais, não são estáticos e podem ser modificados, readaptando-se ao longo do tempo. Portanto, são considerados, pelo autor, "tipos relativamente estáveis" (p. 279).

Diante do exposto, seguiremos com a análise dos modos de dizer tradicionais presentes nas cartas de pernambucanos dos séculos XIX e XX.

\subsection{Os modos de dizer tradicionais das cartas de amigo e de família de pernambucanos do século XIX}

Conforme Silva (2018) destaca, os missivistas empregam nas cartas modos de dizer tradicionais que se aproximam mais de uma relação comunicativa face a face, denominada por Koch e Oesterreicher (2006) de proximidade comunicativa. É justamente essa proximidade comunicativa que revela a carta 


\section{REVISTA DA ABRALIN}

pessoal como um gênero "[...] panorâmico de transições linguístico-discursivas no contexto pernambucano" (SILVA, 2018, p. 17). Nessa direção, Castilho da Costa (2012, p. 151) afirma que são traços típicos de proximidade comunicativa: "[...] a familiaridade com que interlocutores se tratam, a privacidade da comunicação (quer dizer, busca-se um público restrito) e a forte implicação emocional."

As cartas de amigo da segunda metade do século XIX do nosso corpus pertencem a Joaquim Nabuco, líder abolicionista, jurista e político brasileiro, que nasceu em Recife em 19 de agosto de 1849 e faleceu em Washington, em 17 de janeiro de 1910. Desse modo, suas cartas compreendem a década de 1867 (tendo ele 18 anos) a 1896 (tendo ele uns 47 anos de idade) e, de modo geral, têm como temática principal assuntos acerca de política, abolição, viagens e convites. Nesse sentido, destacamos algumas aberturas (saudação) das cartas abaixo:

(1) Expressões de abertura (saudação) da carta de amigo do século XIX:
a. Meo caro Barros (CA06) ${ }^{4}$
b. Meo Caro Adolpho (CA07)
c. Meu Caro Salvador (CA04)
d. Meu caro Alberto (CA05)
e. Meu caro José Mariano (CA08)
f. Barrinhos (CA01)

O uso de possessivos e diminutivos no vocativo (ou saudação) aparece com frequência tanto nas cartas de amigo quanto nas cartas de família do século XIX. Nos exemplos acima, percebemos uma grande intimidade, apesar do assunto das cartas ser sobre política ou convite, na escrita das missivas direcionadas ao amigo Barros. Essa intimidade é evidenciada, no primeiro momento, por, na saudação, empregar-se o nome do correspondente no diminutivo, o que não ocorre em outras missivas.

Temos como exceção às cartas de Joaquim Nabuco apenas uma carta de outro missivista, a carta de amigo de João Gonçalves para o pernambucano Arthur Orlando. O que sabemos é que os dois eram amigos e aliados políticos. Na carta, o remetente inicia a saudação usando o segundo nome do destinatário e encurta a parte de captação de benevolência:

(2) a. Saudação da carta de amigo do século XIX: "Orlando[...]" (CA10)

b. Breve captação da benevolência: "Ultimamente não tenho recebido cartas suas 1 além das que acusei" (CA10).

Durante toda a carta, João Gonçalves trata Arthur Orlando de maneira igualitária, empregando a forma Você e o possessivo de $3^{\text {a }}$ pessoa do discurso ("seu"). Manda notícias sobre acontecimentos políticos e avisa que não tem recebido cartas do amigo. O remetente da missiva se direciona ao correspondente apenas citando o segundo nome uma única vez (cf. (2a)) e, a partir disso, transcorre a carta. Segundo Castilho da Costa (2012, p.154), tanto a abertura quanto o fechamento da carta

\footnotetext{
${ }^{4}$ A codificação CA significa Carta de Amigo e o número é seguindo como consta nos arquivos do corpus selecionado, conforme Costa (2019).
} 


\section{REVISTA DA ABRALIN}

"são a expressão da construção de um relacionamento". Diante disso, podemos dizer que, na carta de amigo de João Gonçalves - e em outras missivas que tenham a finalidade de passar mensagens rápidas e informações sobre acontecimentos -, são a abertura e o fechamento que cumprem a função de demonstração do estabelecimento da amizade, intimidade, como podemos ver no fechamento (conclusão, despedida e assinatura) abaixo:

(3) Os seus gosam saúde. 1 Recummende-me a sua Excelentíssma Senhora e desponha do 11 Amigo certo. || João Gonçalves. (CA10).

O mesmo caminho das cartas de amigo enviadas por Joaquim Nabuco, seguem as cartas de família da segunda metade do século XIX, pois os missivistas Izabel Maria Fragoso, sogra de Arthur Orlando da Sila, e José Mariano Carneiro da Cunha fazem uso recorrente de possessivos, adjetivos e diminutivos na construção do relacionamento na abertura da carta. A diferença reside na relação de assimetria do interlocutor que envia a missiva para os destinatários, pois são missivas escritas de pai ou mãe para seus filhos:

(4) Expressões de abertura (saudação) da carta de família do século XIX:

a. Minha Filha (CF01)

b. Minha Filha (CF02)

c. Minha Filha (CF03)

Através dos exemplos acima expostos, percebemos uma recorrência no modo de realizar a saudação na abertura da carta. Em termos gerais, mãe e filha compartilham assuntos sobre si, saúde dos familiares e lembranças para os seus parentes. As mensagens enviadas por Izabel Fragoso são rápidas e conservam um certo grau de distanciamento, ainda assim, a intimidade se estabelece na captação da benevolência (cf. (5)) e na temática livre do narratio (ou desenvolvimento do texto), como podemos ver em (6):

(5) [...] Todos os dias espero receber car- | ta sua perguntei a Joãosinho | disce elle q' voce a muito não | escreve a elle q' já se esqueceo de | escrever não basta o cuidado | q' tenho em Eduardo. (CF01)

(6) [...] Continuo / em caza de Sinha não tenho po | dido alugar uma caza com | dições em que Doutor quer, acaza deve ser em beiramar para mim tem | sido custoso, hai outra razão | que eu não heide hir. Só Generosa | tinha tratado devir porem | deu em beber não vale nada [fol. 1v] estou vendo se encontro ou- | tro o que é bem custozo em O- | linda se encontra criados. (CF01)

Ademais, observamos que, nas cartas de Izabel Maria Fragoso, há uma atualização no modo de assinar as missivas. Os diferentes modos de assinar evidenciam uma sinalização de possível não manutenção dessa tradição mesmo em uma relação de relativa intimidade e, isso, pode ter relação com 


\section{REVISTA DA ABRALIN}

a própria assimetria descendente dessa relação mãe-filha, como em (7). Nesses dois exemplos, há uma relativa manutenção do modo de despedir-se:

(7) Expressões de despedida e assinatura da carta de família do século XIX:

a. Todos ficamos de saude e | todos mandão muitas lem | branças Pupu fica de saude | manda muitos beijos Papai | e amamãe e abeluca e muitos | abraços atodos e de sua mãe | as saudades que nunca terafim | Lembranças a [Sianinha] Izabel Mª Fragoso (CF01)

b. Todos mandam | lembanças. Pupuzinha manda muitas | saudades a Papai e a mamãe [inint.] | [fol. 1 v] [mui]tos abraços. Lembranças de | seus manos e muitas saudades de | sua mãe || Izabel Fragozo || Deis lembranças a [Sianinha] | Ubaldo manda lembranças | a todos. (CF02)

Dando prosseguimento, José Mariano Carneiro da Cunha, pernambucano abolicionista e político, emprega, nas cartas para a filha, o uso de possessivos, adjetivos e diminutivos. Esse modo de dizer recorrente na escrita de José Mariano tem forte implicação emocional. Sendo assim, tanto a saudação quanto a despedida emolduram a carta com a finalidade de estabelecer intimidade e simetria na relação entre os interlocutores, embora seja uma relação de assimetria descendente, isto é, uma carta remetida do pai para a filha:

(8) Expressões de saudação na carta de família do século XIX:

a. Minha querida filhinha | Yayá. (CF04)

b. Querida filhinha Yayá. (CF05)

(9) Expressão de despedida na carta de família do século XIX:

[...] Adeus minha filhinha. Não | deixa de mandar-me sem-| pre noticias de Olegario. | Aceitem a minha benção || Teu pae do coração || J. Mariano (CF04)

Além disso, as cartas de José Mariano para a filha são iniciadas com cobranças para enviar mais cartas, ou ainda, avisando quais as datas das cartas que as recebeu ou enviou, correspondendo a captação da benevolência, no interior do narratio, como em (10):

(10) a. Tenho recebido apenas | três cartas tuas -, uma | de 6 de junho no dia $20 \mid$ e ante-hontem as | de 24 e 36 de junho que | vieram no mesmo enveloppe | e a de 3 de julho. Li | outras que teus escriptos | não tenho recebido. A | minha ultimas, se não me | engano, foi a 15 de ju-| nho, por intermedio de Galhardo. Depois disso, | por causa dos atropellos | [fol. 2] do serviço da fasenda | onde tenho estado qua- | si sempre e perdi as ma-| las de outros vapores. (CF04)

b. Escrevi-te a 21 deste pelo "Cor-| delliere" e hoje novamente es-| crevo-te pelo "Magdalena" para | dar-te a compensação de não | teres recebido cartas pelo Da-| nubé. É mesmo cumpro a pro-| messa que te fiz em minha ulti-| ma carta de te escrever sem-| pré. || Recebi hontem uma cartinha tua, sem data, mas que pro-| vavelmente devia ser de 19 ou | 20. || A esta hora já deves estar | mais satisfeita porque já | terá recebido a carta que | foi pelo Cordelliere. (CF05).

Retornando à análise das cartas de amigo do século XIX no que diz respeito à captação da benevolência do interlocutor, as cartas de amigo de missivistas pernambucanos têm como 


\section{REVISTA DA ABRALIN}

particularidade forte caráter emotivo em seus modos de dizer permeados de adjetivos e advérbios que auxiliam na exacerbação de sentimentos através de expressões para descrever algum acontecimento ou opinião:

(11) Captação da benevolência nas cartas de amigo do século XIX:

a. Acabo de ter a triste noticia que| dá hoje o Jornal e mando-te| as minhas mais sentidas| saudades de amigo n'este| cruel transe de tua vida. | O laço que te prendia a| teu pai era mais profundo| e complexo do que costuma| ser a affeição filial (CA09)

b. Ultimamente não tenho recebido cartas suas l além das que acusei. (CA10)

c. O anno começa bem para mim porque | recebi hontem a tua carta. (CA06)

A implicação emocional das expressões contribui para firmar a relação de amizade estabelecida entre os correspondentes e, portanto, contribui para constituir a proximidade comunicativa, pois, a partir de expressões que indiquem o estado emocional do missivista em relação com quem se fala, o interlocutor poderá presumir sentimentos de empatia, tristeza, alegria, amor, saudade, raiva, etc. As cartas que tratam de assuntos rápidos, como algumas de Joaquim Nabuco, simplificam o formato composicional e a captação da benevolência acaba por aparecer, por vezes, através de um convite:

(12) a. Como eu tenho hoje a noite tomado por| um compromisso anterior e o Saldanha| só chegou esta manhã, não posso convi-|dar-te senão para jantar commigo- quando| esperava poder ler-te depois o meu| drama (CA04).

b. Ahí são os estatutos do Atheneo e do culto a scien_| cia para que organises os 10 artigos[ inint] || Convida a todos amanhã ás 6 horas.| se quiseres passar á noite por aqui, vem para con|versarmos e fazermos um passeio (CA01).

Esses convites aparecem no começo das cartas desse correspondente pernambucano do século XIX e, por ser uma carta curta, tem o exordium simplificado. Então, a carta já se inicia como uma espécie de captação de benevolência e narratio. Sabemos, pois, que o narratio é o desenvolvimento da carta que abriga a narrativa de acontecimentos e informações sobre o estado das coisas, como em (13a) e (13b). No narratio percebemos também que acaba abarcando, por vezes, outros gêneros, funcionando como uma espécie de jornal (cf. (13b)):

(13) a. Morte de um amigo ou ente querido: Infelizmente | estou sob a terrivel impressao da morte | do Gambetta. Lembras te dos nossos | tempos da Academia? Do enthusiasmo | que nos causava a leitura dos ultimos | actos [ilegível] politicos do Imperio - | a estréa de Gambetta, o discurso do | Plebiscito, a guerra ainda depois | de Metz ! Enfim, a morte representa | ha ' muito esse mesmo papel; somos | nós que demasiado o esquecemos e | temos fe ' na vida (CA06).

b. Notícias políticas: Seguio para o Rio o Capitão Rego Barros que vai de- 1 por no processo de José Mariano ll Elle aqui veio buscar a familia, mas fez crer que l vinha em commissão em busca de documentos con- 1 tra o Barbosa, para por este meio obtel-os mais 1 facilmente, como aconteceo (CA10). 


\section{REVISTA DA ABRALIN}

Castilho da Costa (2012, p. 161), fundamentada em Schronder (2007), afirma que a carta tem como principal papel o estabelecimento da amizade e, nesse sentido, escrever cartas é corresponder a regras determinadas. Por isso, destacamos abaixo uma das regras apresentadas pela autora que encontramos nas cartas de amigo do século XIX, no interior do narrativo:

- Caritas - a obrigação de elogiar a obra lida do amigo:

(14) Meu caro Alberto, || Muito obrigado pelo seu volume, cuja duplicata expedi ao meu a- | migo Rio Branco. || Eu tinha lido o exemplar do Dantas, de uma assentada, como o |C. de Laet. O Gaspar está muito penhorado com as sua palavras a | respeito delle. É inútil repetir-lhe quanto divirjo do seu ideal, | dos métodos Você é | um monarchista que não se conhece a si mesmo, ou por outra que to- $\mid$ ma certos impulsos literarios de sua intelligencia por verdadeira caracteristica do seu tempo. || Lamento político em vez de tomar os instictos profundos do | seu coração. Um desses Catolicos que se julgam atheus e só se sen- | tem religiosos em face de morte, isto é, a primeira que enca- | ram o problema face a face. O fermento litterario ou a fermenta- | cão do meio, não se confunde com o sentimento que brota das fon- | tes da vida. Lamartine republicano de 1848, o que foi? Agora está | se vendo o que foi Michelet (!) e todo o mundo sabe o que V. Hugo | era quando era só poeta. Monarchistas, meu caro, como V.Exelência. o seu livro | (que revela uma tendencia para a reconsideração do caminho feito | e da direção seguida) torna isso evidente para mim. Literariamen- | te falando o que Você escreveu é a unica medida verdadeira e exata | que Você deu até hoje das proporções e da flexibilidade, da sua vida- | de do seu talento e sinceramente o felicito[...] (CA05).

Ainda que o missivista tenha tecido críticas à obra lida, não deixa de elogiar a obra do interlocutor. Outras regras devem ser seguidas, como exprimir modéstia, mostrar interesse pelo interlocutor, lembrar que as missivas podem ser extraviadas, mas, a primeira delas, é a obrigação em responder a carta que foi recebida, como lemos as reclamações que temos observado nas cartas. Um aspecto interessante em (14), assim como em outras cartas, é que a forma de tratamento Você é escrita com letras maiúsculas. Isso pode indicar um conservadorismo do caráter cerimonioso dessa forma de tratamento. O exemplo acima refere-se a uma carta de fins do século XIX, trocada entre amigos de vida pública e, portanto, embora o tratamento seja igualitário, conserva-se um tratamento altamente respeitoso.

Diante do exposto, ao direcionarmos o olhar para as missivas de família e de amigo do século XIX, percebemos que, no desenvolvimento de algumas cartas, os missivistas, por meio de expressões modalizadoras (com o uso do subjuntivo), ou ainda, o uso de imperativo, em um dado momento da missiva, tem intenções de pedir ou indicar que o destinatário realize algo que o missivista deseje:

(15) Expressões de pedido em cartas de amigo do século XIX:

a. [...]Peço-lhe que torne publico|o meo prothesto contra o novo trafico de ingenuos que| começa[...] (CA07)

b. [...]Mas como tu és bom pai de| família e não te custa deixar nehuma| companhia as dez horas para voltar|[ fol.1.r]para casa, se quiser darme o | prazer de estares aqui ás sete horas| hoje - nos jantaremos[...] (CA04).

c. [...]A carta junta Você remeterá para $\underline{\text { Santos }}(\mathrm{CA1})$. 


\section{REVISTA DA ABRALIN}

(16) Expressões de pedido da carta de família do século XIX:

a. [...]Manda dizer todos como tem passado. [...] Pupuzinha manda muitas | saudades a Papai e a mamãe [...] (CF02)

b. [...]Mande dizer < $\uparrow$ voce > como tem | passado e Belluquinha e Doutor Orlando | não deixe de escrever dando noticia | izata[...] (CF03)

c. [...]Não deixes de me es-|crever sempre. [...]Não | deixa de mandar-me sem-| pre noticias de Olegario. | Aceitem a minha benção[...] (CF04)

A conclusão das cartas de amigo do século XIX é bem diversificada com a presença de expressões formulaicas de despedida (17 a), de expressividade emocional no uso linguístico, em (17a) e (17b), e votos (17c):

(17) a. Adeus, meu querido Amigo.| Eu que passei por um golpe| egual sei o que é essa primeira| morte que se morre na| vida. Do teu Velho Querido|| Joaquim Nabuco. (CA09).

b. Soa muito incon [ilegível] | como sabes, mas nunca mudei de principios | nem de amisades. Teo sempre o mesmo || Joaquim Nabuco (CA06).

c. Cada dial mais eu te invejo - fazendo votos para que| não voltes tão cedo á esta < $\uparrow$ capital>do café. [inint.] à Voz\| Joaquim Nabuco (CA02).

Todas as cartas acima são do missivista Joaquim Nabuco para diferentes interlocutores. Nesse sentido, o remetente adequa o fechamento da missiva de acordo com a finalidade comunicativa. Enquanto nos exemplos (17a) e (17b) há forte implicação emotiva, demonstrando sentimentalidade e compadecimento pelo outro (este último caso em (17a), já em (17c) o remetente é mais objetivo, não formula uma expressão de despedida e, logo após, finaliza com a assinatura. É notado que as expressões de despedida, quando há, são carregadas de expressividade e carregam o compromisso de firmar o estabelecimento da amizade (CASTILHO DA COSTA, 2012). Diante desse fato, o uso de possessivos e adjetivos ressaltando valores ou qualidades de si ou de outros (como em "Do teu velho querido", ou ainda, em "Teu sempre o mesmo") indica a intimidade e a relação de uma amizade duradoura.

Na carta de João Gonçalves, ao nos voltarmos para despedida, encontramos a mesma expressão formulaica de despedida do exemplo (18), "Amigo certo". Para além disso, a presença de verbos como recomendar, mandar e lembrar aparece como modos tradicionais de dizer, geralmente no fechamento do texto, nas missivas do século XIX. Esses modos tradicionais de dizer não são escolhidos livremente no acervo da língua, mas são reproduzidos ou repetidos de modelos linguísticos já anteriormente conhecidos, assim também atesta Castilho da Costa (2012). Sendo assim, o verbo recomendar, presente no exemplo (18b) da CA10, é evocado no contexto de querer transmitir cumprimentos ao coenunciador, seja de terceiros ou ainda podendo ser o coenunciador do próprio remetente:

(18) a. Amigo certo || João Gonçalves (CA10)

b. Os seus gosam saúde. | Recummende-me a sua Excelentíssma Senhora e desponha do || Amigo certo || João Gonçalves (CA10) 


\section{REVISTA DA ABRALIN}

Por fim, após apresentar na despedida um apelo às emoções, lembranças, pedidos, conselhos e cumprimentos, o enunciador finaliza a carta com uma expressão formulaica, que também indica emotividade e, finalmente, coloca o ponto final após a assinatura ou rubrica:

(19) Expressões formulaicas de despedida e assinatura da carta de amigo do século XIX:
a. Todo teu| Joaquim Nabuco.| Buckingham (CA04)
b. Teo sempre o mesmo \| Joaquim Nabuco. (CA06)
c. Seo do Coração. [assinatura] (CA07)

Dessa maneira, os interlocutores das missivas de família e amigo do século XIX se utilizam de diversos modos de dizer tradicionais, evocando, repetindo e, também, atualizando-os de acordo com a finalidade comunicativa da carta e com a relação estabelecida entre os interlocutores.

\subsection{Os modos de dizer tradicionais nas cartas de amigo e de família do século XX}

Em relação ao contexto de produção das missivas, no século XX, o Brasil passa por intensas transformações, mais especificamente, o estado de Pernambuco é marcado por intenso e acelerado processo de urbanização e industrialização. Conforme afirma Silva (2018, p. 63), no século XX, houve mudanças consideráveis no que diz respeito a acontecimentos históricos e sociais:

\footnotetext{
No contexto brasileiro, passamos por um acelerado processo de urbanização e internacionalização da economia, principalmente a partir da década de 1930, com a Era Vargas. O Brasil viveu 21 anos de regime militar e foi regido por seis constituições no século XX. Linguística e textualmente, o Brasil passou por várias mudanças ao longo do século XX. Ao todo, no país, houve duas reformas ortográficas: em 1943 e em 1979. Várias mudanças no português brasileiro foram ocasionadas por estrangeirismos, neologismos e gírias.
}

Diante desse contexto de produção, de modo geral, as cartas de amigo e de família do século XX abarcam assuntos relacionados à política, ao estado das coisas, à apresentação de terceiros, à tentativa de reaproximação de uma amizade, ao falecimento de terceiros, à falta de tempo e dinheiro, à solicitação de empréstimo, notícias sobre si, notícias sobre o interlocutor e sobre familiares, amigos do remetente ou de terceiros, recomendações, lembranças, elogios, etc. Essas missivas se diferenciam das do século XIX, pois, ao longo do século XX, vamos percebendo, nas escolhas de tratamento, que as relações (igualitárias ou hierárquicas) vão se transformando, a exemplo do uso da forma Você que vai sendo usada de forma generalizada em substituição a forma Tu para indicar o grau de intimidade da relação.

Os modos de dizer tradicionais das cartas de amigo e de família do século XX nos mostram algumas pequenas atualizações (de vocativo ou saudação da carta) em relação às cartas de amigo e de família do século XIX. Nas cartas do século XX, verificamos alguns conjuntos de tradições além do gênero, ou seja, diferentes conjuntos de tradições presentes nas interlocuções de missivista para 


\section{REVISTA DA ABRALIN}

missivista, dependendo da relação existente entre eles. Isso ocorre, sobretudo, por cada carta do século XX ter um autor diferente, tendo, portanto, modos tradicionais de dizer que, por vezes, se diferenciam um do outro, ou ainda, são recorrentes:

(20) Expressões de abertura (saudação) da carta de amigo da primeira metade do século XX:
a. Arnaldo, meu grande amigo (CA15)
b. Meu caro Arnaldo (CA16)
c. Borba (CA14)
d. Meu caro Paranhos (CA12)
e. Antonio Correia (CA13)
f. Meu muito caro Decio Silveira (CA17)

(21) Expressão de abertura (saudação) da carta de amigo da segunda metade do século XX:
a. Meu querido Caio [Benjamin Dias] (CA18)
b. Meu caro Gilberto Freyre: (CA20)
c. Meu querido NELSON FERREIRA (CA18)

Utilizam-se ainda com frequência do possessivo e, em (20a), ao saudar o amigo, acrescenta-se a explicação ao vocativo. Há atualizações nas missivas, também, compostas por novos elementos linguísticos atuando na expressividade, na saudação de uma carta de amigo do final do século XX, conforme exemplo a seguir:

(22) meus Cordial bom dia \| querida Amiga (CA21)

Sobre a abertura da carta de família, podemos perceber as diferenças de tratamento, ou seja, a assimetria ou simetria entre os interlocutores e isso é, sobretudo, evidenciado pelo vocativo da missiva, como mostram os seguintes exemplos:

(23) Expressões de abertura (saudação) da carta de família da primeira metade do século XX:

I. Carta enviada de filho(a) para mãe:
a. Minha Mãe. (CF39) ${ }^{5}$
c. Mamãe \| Abenção (CF54)
d. Minha boa mãe (CF09)
e. Minha adorada (CF08)
f. Cara Mamãe (CF17)
g. Minha boa (CF23)
h. Minha querida (CF24)
i. Minha querida mãesinha (CF25)
j. Querida Mamãe (CF28)

\footnotetext{
${ }^{5}$ A codificação CF significa Carta de Família e o número é seguindo como consta nos arquivos do corpus selecionado, conforme Costa (2019).
} 


\section{REVISTA DA ABRALIN}

II. Carta enviada de mãe para filho(a):

a. Maria (CF13)

III. Carta enviada de filho(a) para o pai:

a. Papai|| Abençam (CF52)

b. Papai\| Abenção (CF55)

IV. Carta enviada de pai para filho:
a. Ignes (CF31)
b. Rita (CF33)
c. Mercês (CF34)
d. Querido Hoel (CF40)
e. Meus queridos Hilton, Lucia e Bibizinha. (CF47)
f. Meus queridos filhos. (CF46)

V. Carta enviada de irmã para irmã:

a. Minha irmã (CFO7)

VI. Carta enviada de primo para primo:

a. Caro Gilberto (CF48)

b. Meu caro Gilberto (CF50)

Nas cartas familiares, os pais, em uma posição de assimetria descendente, utilizam principalmente apelidos carinhosos, diminutivos, adjetivos antes do nome para estabelecer um diálogo mais íntimo com os filhos, mandando notícias e falando das saudades, como em (23 I) (23 IV (d, e, f)). Alguns pais apenas escrevem o primeiro nome do filho e, consequentemente, o assunto dessas cartas geralmente fala de notícias dos pais, burocracias documentais, saudades, com uma menor expressividade emocional nas palavras, como em (23 II) e (23 IV (a, b, c)). No que diz respeito aos filhos, estão em uma relação de assimetria ascendente, fazem uso das expressões "mamãe", "papai", "mãezinha", "pai", "mãe", às vezes, precedido de adjetivos, como podemos observar em "minha boa mãe", às vezes, precedido de adjetivos, como em (23 I, II e III)). Em (23 III), há também o ato respeitoso de pedir a benção, o que indica uma relação mais cerimoniosa. Nas cartas trocadas entre irmãos (23 V) e primos (23 VI), estabelece-se uma relação de igualdade.

As missivas de fins ${ }^{6}$ do século XX obedecem à presença de maior parte das características composicionais da carta pessoal, com duas missivas mais curtas e com o formato simplificado. Nessas missivas de família, temos formas mais atualizadas de saudação, com os missivistas utilizando expressões mais comuns da época como "Prezado" ou ainda "Meu abraço", esta última muito presente no fim de cartas de amigo do século XIX. Outro fato interessante é em relação às cartas de (24c) e (24d) serem direcionadas a todos os entes da família. Observamos também a presença da palavra "saudação" indicando uma forma de dizer que conscientiza sobre a estrutura da carta:

\footnotetext{
${ }^{6}$ No tocante às expressões tradicionais de abertura ou saudação das missivas de família de fins da segunda metade do século XX, são distintas no que diz respeito ao perfil social dos missivistas da primeira metade, pois eles têm maior grau de escolaridade em relação aos missivistas da segunda metade.
} 


\section{REVISTA DA ABRALIN}

(24) Expressões de abertura (saudação) da carta de família da segunda metade do século XX:

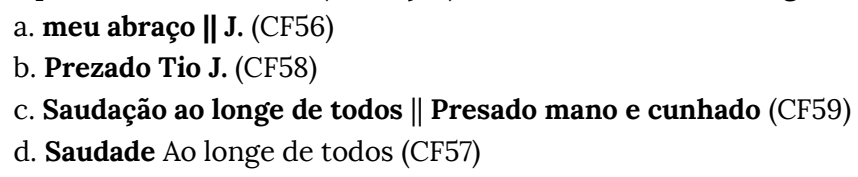

A Captação da benevolência do interlocutor nas cartas de amigo do século XX possui um teor altamente emocional que é expresso através de elementos linguístico-discursivos agindo na argumentação do remetente para o convencimento e manutenção da interação entre os interlocutores (CASTILHO DA COSTA, 2012):

(25) Captação da benevolência na $1^{\mathrm{a}}$ metade do século XX em cartas de amigo:

a. Estava em falta comtigo, | Por não poder te escrever, | Mas não foi por pouco caso,| Ao contrario, o grande atrazo| Foi bem contra o meu querer || Foi a causa deste mal,| A minha vida actual,| Que sendo activa de mais,| Tem sempre prejudicado,| O cumprimento sagrado,| Dos deveres sociaes.(CA15)

b. Mando a Você meus parabens pelo dia de| hoje, cuja data ha de sempre recordar al do dia feliz em que Você poude, com honra| e desassombro, desencarregar-se, enfim, de| governar o estado. (CA16)

c. voce não ia de acreditar, e entre- | tanto é a verdade, que eu agora ando | mais quebrado do que sempre andei (CA13)

d. Tendo ido a São Paulo e não podendo ver Você, por estar ausente da ca-|pital, tive uma impressão parecida a de haver ido a Paris, sem visitar o Louvre; á Napoles sem conhecer Pompeia; á Lisboa sem subir até Cintra; á Hollanda sem |admirar suas tulipas[...] (CA17)

Nos exemplos acima, observamos que em (25a) o missivista procura justificar suas faltas para com o amigo dizendo que tem uma grande quantidade de atividades diárias que não o deixam escrever. É praticamente categórico encontrar no corpus cobranças de respostas do remetente ao destinatário. Assim, mais uma vez, reforçamos que a primeira regra de interação entre os missivistas é a obrigatoriedade em responder e, consequentemente, ser respondido. Já em (25b) e (25d), observamos a manutenção da amizade através de uma regra de escrita de cartas denominadas bienveillance, isto é, apresentar interesse pelo interlocutor, e a bienséance, que corresponde a buscar diminuir-se, para então, elogiar o destinatário (BRUGYSSER, 1993 apud SCHRODER, 2007, p. 156). Em (25c), acreditamos que a sentença destacada representa uma validação do afirmado pelo missivista da previsão de um possível julgamento negativo que o destinatário poderia pensar sobre o seu interlocutor. Nos exemplos (25b) e (25c), podemos visualizar, mais uma vez, a grafia da forma de tratamento Você ser diferenciada em maiúsculo e minúsculo, ainda que, na escrita de dois missivistas diferentes, os dois são da primeira metade do século XX.

As cartas de amigo ou de família que têm como assunto pêsames pela morte de algum ente querido, independentemente se são do século XIX ou XX, possuem forte implicação emocional, através de termos linguístico-discursivos (como adjetivos, advérbios modalizando o discurso, lembranças sobre o entre, etc.), que garantem a estas cartas emocionalidade, empatia, compadecimento ou tristeza. A carta CA16 tem um caráter muito poético e, após o remetente, Lourival, mostrar-se 


\section{REVISTA DA ABRALIN}

compadecido com o seu interlocutor (Arnaldo Guedes), escreve um poema de sua autoria para "[...]soar aos ouvidos de tua alma amiga[...]":

(26) Pae, como tu, bem aquilato da tua dôr immensa, ven- | do fugir para o desconhecido, si bem que para mim este desço- | nhecido seja a eternidade feliz, o ente querido que era bem / um pedaço de tua alma esplendida. Recebi, ha poucos dias, um postal - photographia do | teu filhinho no seu leito de morte. Escusado é dizer que a - | impressão causada no meu espirito foi bastante emocionante, | fazendo uma Idea do quanto Vocês ahi soffreram, paes, avós, | toda a familia. || Foi justamente pensando na | tua dôr, da qual compartilho, que fiz e faço soar aos ouvidos | de tua alma amiga[...] (CA16)

A captação da benevolência em cartas de amigo da $2^{a}$ metade do século XX também apresentam as regras de bienveillance e de bienséance, como visualizamos a seguir:

(27) Captação da benevolência na $2^{\mathrm{a}}$ metade do século XX em cartas de amigo:

a. De alma embandeirada, radiante, amanheci mergu- | lhado num oceano de felicidade, pois sabia que um grande | amigo amanheceria enriquecendo as páginas dos jornais, an-|te a noticia alviçareira de ter recebido o pomposo titulo | de CIDADÃO DO RECIFE. (CA19)

b.Estive apenas dias na Cosal | em Dortmund e cada vês mais me orgulhei | pernam bucanamente, do prestigio do seu nome | e de sua obra aqui na Alemanha. (CA20)

c.é com | muita saudade que pego | este lapis para darte as | minhas noticia e ao | mesmo Tempo saber das | Tuas (CA21)

As missivas dos exemplos acima são permeadas por exageros e simbolismos, têm características bastante poéticas. Os correspondentes se utilizam de hipérboles (27a), adjetivações (27b) como recurso linguístico para expressar afetividade e emocionalidade. A carta CA21, exemplo (27c), foi escrita por um missivista com pouca escolaridade e, ainda assim, percebemos presentes na carta os modos recorrentes de dizer, igualmente, seguindo regras de interação, como o estabelecimento da amizade. Sobre essa questão, Koch e Oesterreicher (2006) expõem que o estabelecimento da amizade se constrói na carta através do grau de intimidade com que o enunciador de forma expressiva e afetuosa enaltece o coenunciador. Sendo assim, para que a amizade seja estabelecida, deve haver sempre uma espécie de ativação da emocionalidade sendo dirigida ao interlocutor (KOCH; OESTERREICHER, 2006).

Destacamos seis principais exemplos de captação da benevolência, dos quais três são do missivista Manoel Borba para suas filhas e os outros três exemplos são de Valdemar de Oliveira para sua mãe. Logo, buscamos observar nos exemplos abaixo uma relação assimétrica descendente (carta escrita por um interlocutor em uma posição hierárquica superior à posição do destinatário, como pai escrevendo para filho) e uma relação assimétrica ascendente (carta escrita por um interlocutor em uma posição hierárquica inferior à posição do destinatário, como filho escrevendo para a mãe):

(28) Captação da benevolência na $1^{\mathrm{a}}$ metade do século XX em cartas de família:

a. Mercês|| Aqui em Goianna recebi hontem | sua cartinha que me deu muito | praser (CF32)

b. Rita|| Recebi sua cartinha muitol pequenininha muito laconica| mas mesmo assim me deu| muito praser. (CF33) 


\section{REVISTA DA ABRALIN}

c. Ignes || Hontem lhe telegraphei em resposta ao seu | telepgramma em que me dava a opinião. (CF31)

Nas missivas acima de Manoel Borba para as filhas, a captação da benevolência em (29a) e (29b) tem como forma recorrente "sua cartinha me deu muito prazer", buscando estabelecer a amizade e a intimidade entre os missivistas. Essas cartas são de grande expressividade emocional que é fixada na captação da benevolência e na despedida; o narratio é o lugar no qual o missivista fala sobre seu estado de saúde e realiza algum pedido. As cartas que não têm captação da benevolência são aquelas que tratam de assuntos mais urgentes, como o pedido para realizar algum favor (cf. 29c). Já as cartas enviadas pelo filho Valdemar de Oliveira a sua mãe Maria da Penha, de modo geral, são bem intimistas, levam notícias sobre si, sobre suas viagens e sobre os estudos que tem realizado, além de pedir dinheiro para ele se manter e pagar as despesas, conforme apresentado a seguir:

(29) Captação da benevolência na $1^{a}$ metade do século XX em cartas de família:

a. Cheguei e com saúde | Fis a viagem bem, só com o incove- | niente de muito pó (CF17)

b. Com grande satisfação recebi a | sua encommenda trasida pela sr. Alves (CF16)

c. Recebi e podes avaliar bem a mi- | nha alegria ao ler a sua cartinha | de 8 deste, trasida pelo bom amigo (CF18)

As cartas de família da segunda metade do século XX englobam, em sua captação da benevolência, o modo de dizer tradicional em desejar bonanças aos seus interlocutores, como podemos observar no início das missivas (cf. (30a), (30b) e (30d)). Ainda no exemplo (30b), o missivista adianta na captação da benevolência uma espécie de resumo das notícias sobre si e sobre a família dizendo que está bem. No exemplo (30c), a captação da benevolência adianta o objetivo da carta e, durante a carta, a missivista pergunta pelos seus entes queridos:

\section{(30) Captação da benevolência na $2^{\mathrm{a}}$ metade do século XX em cartas de família:}

a. desejo que | linhas o encontre com saúde e felicida- | de. (CF58)

b. [...] primeiro do que tudo Deus ti a bençoi, | ti proteija juntamente com tua familia | Quanto a eu, e minha familia estamos em I paz graças a Deus. (CF56)

c. Ao te escrever estas pequenas linha |É para da as minhas notícias | E ao mesmo tempo Saber as suas (CF59)

d. Primeiro do que tudo espero que estas | Pequenas linhas o encontre todos da familia | gozando saude e muita felicidade. (CF57)

Sabendo que o desenvolvimento ou núcleo da carta (narratio) é a parte na qual os interlocutores articulam a razão pela qual estão escrevendo, dentro do próprio narrativo, situam-se conjuntos de tradições, uma delas diz respeito a uma das diversas funções sociais da carta. Como já mencionamos, uma dessas diversas funções é o estabelecimento da amizade. Esse estabelecimento ocorre através da consolidação do contato que se dá ao se responder a missiva recebida a partir do grau de intimidade entre os missivistas e que se é revelado através da expressividade emocional nas escolhas linguístico-discursivas da missiva. Por isso, para além do que verificamos nas missivas do século XIX, 


\section{REVISTA DA ABRALIN}

observamos o caráter poético presente no interior do narratio em cartas de amigo e família do século XX. Percebemos também que esse caráter auxilia no exagero das expressões, a fim de causar emoção e consolidar a amizade.

Os modos de dizer do narratio nas cartas de família do século XX apresentam-se através das notícias sobre si e sobre os entes queridos, igualmente às missivas do outro século e do outro subgênero, mas as cartas de família do século XX trazem também o diferencial das assimetrias nas relações (BROWN; GILMAN, 1960). Nesse sentido, observamos que as cartas remetidas pelos filhos às mães têm temática mais livre e uma maior implicação emocional, revelado através do caráter apelativo das expressões, do que as cartas remetidas aos pais, ou ainda, em relação às cartas que os pais remetem aos filhos. Estas geralmente abarcam questões pragmáticas sobre realizar algum favor ao pai, falar sobre algum acontecimento familiar e, em algumas dessas cartas, a implicação emocional para o estabelecimento da amizade fica contida apenas na abertura e fechamento da missiva, como em (31):

(31) Modos de dizer no narratio da carta de família da primeira metade do século XX:

a. Rio 23 de Agosto de 1925. || Ignes. || Como vão todos os nossos? Eu vou passan-| do bem, não levando em conta a comida do | hotel que anda muito ruim, mesmo para | mim que sou facil de contentar. || Pelo telephone me communiquei com | Tonita que me disse para deixar o dinheiro | de suas ecommendas na rua sete de setembro | 101, o que fis no mesmo dia. Depois não a | vi e nem pelo telephone fallei com ella, mas certa-| mente Ella procurava o dinheiro. || Miss Helena que vi [init.] | mais feia do que sempre, disse a Cotia que | Você estava noiva. A Cotia me perguntou disen-| do que estava com vontade de mandar pa-| rabens o que não tem por lhe haver eu dito | com a noticia era maluquice de Miss Helena. [Folha 1v.] isto de com os remedios que ella estava to- | mando. | Go A. Vasconcelos está na Europa. | Escrevi hontem por Ademar Tavares. || Já dei nosso nome para o "Galvia" que | deverá passar de volta aqui no dia 18, de | hoje a 15 dias. Deus queira que corra | tudo bem e possamos ir, melhorada | e estabelecida ella. || Nada mais disse de mamãe. || Adeus. Saudades e abraços | do Pai e amigo | M. Borba. (CF36)

As cartas de família da segunda metade do século XX que compõem o nosso corpus apresentam, em seu desenvolvimento, notícias sobre a saúde dos familiares e sobre a saúde do próprio remetente. A relação é respeitosa e há pouca implicação emocional na escolha dos modos de dizer, entretanto, como já vimos em exemplos anteriores da carta de família do século XX (segunda metade), por vezes, essa implicação emocional fica relegada às partes de abertura e fechamento da missiva:

(32) Modos de dizer no narratio da carta de família da segunda metade do século XX:

[...] eu recebi as suas carta | fiquei muito contente. || olha eu não respondeo não foi por | nada que quem escreviu sempre para | mim e a I. mais este dias | Ela teve uma grande luta com o marido | Que foi enternado duas Vezes | Então não deu para ele escrever. | Agora estou na casa do B. | Ele foi quem escreveu para | mim esta carta. || S. como que passou o natal | E o Ano novo? | por aqui foi Tudo Bem graças Deus | S. eu já fiquei Boa | Do meu sangue eu me tratei muito | E compri com o regime direitinho. || Já fiz trez ezame e não deu mais | nada. || S. Você [rasura] e Sandra | Já escreveram para mandaram | todas as noticia mais não mandou | me dizer nada soubre o S. |como que ele vai de saude. || E a ana tambem Se já apozentou | Eu fico preocupada com Vocês[...] (CF59) 


\section{REVISTA DA ABRALIN}

Por conseguinte, encontramos uma breve carta de amigo da primeira metade do século XX cujo tamanho se iguala ao de um simples bilhete, entretanto, ao lê-la, vemos que tem o formato composicional e modos de dizer da carta pessoal, sendo que de modo simplificado:

(33) Modos de dizer no narratio da carta de amigo da primeira metade do século XX:

Meu caro Paranhos, ||Quero ter o prazer de apresentar-lhe $\mid<0$ meu $>$ amigo dezembargador| Domingos Alves Ribeiro. É um dos meus| mais íntimos amigos, e devo essa amizade| ao Dantas, e tambem, indireta-| mente, ao José Bonifacio. De ambos elle| foi amigo dedicadissimo. <Por minha vez>| [inint. 2 linhas] a [init.] ao nos| do Eduardo Prado, que| não teve no fim da vida amigo maior. Como Você vê, não| é uma apresentação commum| que [inint.] lhe faço. $<$ O meu papel limita-se a $>\mid$ pol-o em contacto com Você $<$ O resto [init.] | me dirão algum dia.> || Do seu sempre dedicado\| J. Nabuco 14 de março de 1904 (CA12)

Assim como nas cartas de amigo da primeira metade do século XX, em muito se exalta o interlocutor no interior do narratio com adjetivos, expressões interjetivas para expor emoções, apelos, sentimentos, sensações e estado de espírito na carta pessoal, como verificamos em (34):

Modos de dizer no narratio da carta de amigo da segunda metade do século XX:

No gabinete do diretor do Instituto, o Prof. (Stieger) | lá estava um bom retrato seu e o prof. Stieger | se referiu a voce e à sua obra com um carinho | e um respeito que muito sensibilizaram a | minha "pernambucanidade". Em Colonia, Ham | burgo, Berlim ouvi também um verdadeiro hi- | no de louvor a seu nome ilustre e à Casa | Grande \& Senzala. Isso é bom porque dá uma | ideia de alto nível da cultura brasileira. No | Instituto Ibero Americano de Berlim seu nome foi | referido não somente como a mais alta expressão |do pensamento brasileiro, mas como o de um | dos maiores sociologos contemporâneos. (CA20)

De igual modo, encontramos missivas de amigo e de família, em fins da segunda metade do século XX, com o narratio tendo o exordium simplificado, contendo o início e o final das cartas condensados com o intuito de receber respostas rápidas:

(35) Carta de amigo da segunda metade do século XX:

Timbaúba e de Fevereiro de 1980 || meus Cordial bom dia || querida Amiga é com | muita saudade que pego | este lapis para darte as | minhas noticia e ao | mesmo Tempo saber das | Tuas: A. S. Você | não escreveu mais par | mim porque Você já | Esqueseu de mim pois | eu lembro de Você Todos os | dias so não escrevir mais | par Você porque não | tinha Tempo pariso uma metira A. L eu trabalhava no Hospital e | não tinha tempo nem par | me cosar mais graças a Deus | agora eu sair trabalhor na Associação dos fornecedores de | cana de acucar agora eu | tenho mais Tempo espero | que Você me entenda: | Termino com beijo e abraço | da amiga $\mathrm{G}$ (CA21)

A carta acima, apesar de ter a estrutura condensada, provavelmente para repassar informações que o missivista acredita serem mais urgentes, possui local, data, abertura (saudação), cobra-se por resposta, fala sobre o estado das coisas e ainda possui fechamento, com despedida breve e assinatura. O mais importante é que ainda assim a carta segue o conjunto de tradições do gênero carta pessoal e procura seguir a regra de interação de escrever e querer ser respondido, mostra interesse no interlocutor. Ademais, pelo assunto da missiva, identificamos alto grau de intimidade. Em 


\section{REVISTA DA ABRALIN}

contrapartida, encontramos também uma carta passiva (cf. 36) muito longa de um amigo não identificado de Nelson Ferreira, compositor recifense de frevos, na qual exalta o destinatário sem poupar palavras, usando expressões sentimentais e interjetivas. Esta carta de amigo é da segunda metade do século XX:

(36) [...]Era NELSON FERREIRA. Era o símbolo | de uma época inolvidavel nas dobras do Século XX, um nome | que é uma bandeira, que é uma constelação inteira no bri- | lho de um céu de sinceridade; de bondade espiritual; de no- | breza de carater; de tudo quanto possa elevar o nome de um | homem sadío que nunca soube chorar. Rir foi sempre o apa- | nágio do novo agraciado pelos poderes municipais. Com o co- | ração transbordante daquela clareza que sempre foi minha | irmã gêmea, posso afirmar que, muitos e muitos dêsses expre | sivos títulos teem sido conferidos a vultos de todas as es | pecies, de todas as classes, mas nunca de tanta expressão | como o que lhe coube: VOCE FOI SEMPRE FELICIDADE PARA A CI- | DADE DO RECIFE, FOI SEMPRE ALEGRIA, FOI SEMPRE PAZ DE ESPI- | RITO, FOI SEMPRE O VENDEDOR DE VIDA E BOMHUMOR EM FAVOR DA | FELICIDADE DOS OUTROS, FOI SEMPRE O DONO DO RECIFE QUE, A- | GORA, LHE TIRA O CHAPÉU, EM SOBERBA REVERENCIA[...] (grifos do autor da carta) (CA19)

Ainda sobre as cartas de amigo da $2^{\mathrm{a}}$ metade do século XX, localizamos um pedido, este pouco frequente nas cartas de amigo nas duas metades do século. Entretanto, esse pedido encontra-se no início da missiva, diferente da localização em cartas de amigo e família do século XIX, pois, nessas, o pedido, geralmente, estava inserido no final da carta, antes da despedida e da assinatura.

(37) Pedido no início da carta de amigo da segunda metade do século XX:

Meu querido Caio [Benjamin Dias]|| Junto lhe envio uma carta afim de Voce me fa-|zer o especial favor de fazela chegar às maõs de | Dona Neusa Brizola, pois naõ sei se ela permanece | em Palacio, com essas andanças do Governador[...]. (CA18)

Os pedidos da carta de família do século XX das duas metades do século são muito frequentes e não só no final da carta, conforme ilustram os exemplos abaixo. Independentemente do tipo de relação, podem aparecer no começo após a saudação; no meio da missiva após informar o objetivo e, por fim, pode aparecer antes da despedida, no final da carta:

(38) Expressões formulaicas de pedido na carta de família da primeira metade do século XX:

a. Pedido no começo (exordium) da missiva: Mercês || Aqui em Goianna recebi hontem | sua cartinha que me deu muito | praser. || Quando me escrever novamente | (si ainda houver tempo) diga si | Foi por doente que a Noemia foi | para o interior de Minas. (CF32)

b. Pedido no meio (narratio) da missiva: Se não lhe custar | um sacrifício acima do | que for possivel veja se | e acertado mandar logo os $\mid$ meus troços porque eu | agora tenho que entregar | esta casa porque acaba-se | o contracto e vou ficar | mesmo com uma casa | completamente vazia. (CF39)

c. Pedido no final (peroratio) da missiva: Da uma busca na gaveta de minha se-| cretaria e n'uma pasta (a menor) de papeu | carta que costumava estar na mêsa de | centro do meu gabinete e me manda | todos os recibos e papeis da "Sul America". || Há na pasta e na gaveta, apolices reci-| bos, um contrato de emprestimo etc. Manda | tudo que achares. Eu deixei ahi duas | pastas, a menor e a que tem os papaeis e do- | cumentos a que me refiro. (CF37) 


\section{REVISTA DA ABRALIN}

Relativo aos modos tradicionais de pedir, os interlocutores das cartas de família da primeira e segunda metades do século XX utilizam-se de expressões do modo subjuntivo para indicar possibilidade de realizar a tarefa ou favor que o remetente deseja e, ao mesmo tempo, usam verbos no imperativo para indicar a tarefa ou favor que deseja ou dar as instruções para o destinatário realizálas. Observem-se os exemplos abaixo:

(39) Expressões formulaicas de pedido na carta de família da segunda metade do século XX:

a.Tio J. entregue este Bilhete | Para madrinha S. (CF57)

b. nunca se esquece de mim $\mid$ meu filho (CF56)

c. A mãe | é que anda muito doente devido aos pro- | blemas que Você já conhece, ela manda lem- | branças à todos e pede o endereço de Tio (CF58)

d. [se] der lembrança para lia | fala para ela que eu ainda estou vivo | fala para ela escrever para min. | madrinha E. manda muita | lembrança para Senhora (CF59)

Como já comentado, o peroratio da carta é formado pela conclusão, seguido da assinatura (subscripto). Segundo Castilho da Costa (2012), o peroratio pode contar com um apelo às emoções (solidariedade, indignação) e com um recapitulaio (ou recapitulação), que seria um resumo do que foi apresentado. Passemos, então, a observar as expressões de despedida e assinatura das cartas de amigo e de família do século XX:

(40) Expressões de despedida e assinatura (fechamento) da carta de amigo da primeira metade do século XX:

a. Você quando se resolve a dar um passeio até o Recife? Não preciso | lhe repetir que estarei sempre ansioso de acolhel-o. ||Por hoje só. Vamos a ver si Você agora me escreve: Abrace com affecto e gratidão o \| M. Sete (CA17)

b. Um abraço emotivo para todos os teus. Para a tua querida | pessôa, a alma entristecida mas sempre amiga do || teu [inint.] corde || Rio, 24 de Julho de 1930.|| Lourival || [endereço] (CA16)

c. Cada passo encurta o caminho do tu-|mulo. Console-se com a visão e com a| esperança do seio bem aventurado da| natureza, do repouso eterno![fol. 2v] || Para ora [inint.] do aconchego acolhe-|dor, leal e bem [inint.] da familia - da| esposa e dos filhos que são os unicos| amigos de Você. \| Que Deus abençoe a todos!|| São os votos pollidos do pequeno amigo. || Aurelio Domingues || Recife, 18-12-919 (CA14)

Os exemplos acima expõem a expressividade dos modos tradicionais de dizer atuando a partir de elementos linguísticos que indiquem proximidade comunicativa, como: "por hoje só", "Abrace com affecto e gratidão", em (40a); "Um abraço emotivo para todos os teus", em (40b) e, por fim, a expressão interjetiva como apelo emocional "Que Deus abençoe a todos!", em (40c). Ao analisarmos as missivas, observamos que o assunto e o modo tradicional de assinar dos diferentes missivistas podem dar pistas sobre o grau de intimidade entre os interlocutores.

De igual maneira, nas cartas acima, também observamos que os correspondentes seguem (de forma não consciente) regras tradicionais de interação, por exemplo, a missiva (41a) tenta ser descontraída e humorada (agrément, cf. SCHRONDER, 2007) para não entediar o destinatário, e, na missiva (40c), o missivista segue a regra de não falar tanto de si para exaltar, confortar ou elogiar o 


\section{REVISTA DA ABRALIN}

destinatário (bieséance, cf. ibid.). A missiva, a seguir, destinada a Arnaldo Guedes, segue a regra interacional de não preocupar o amigo com importunações ou problemas (retenue, cf. ibid.):

(41) Expressões tradicionais de despedida e assinatura (fechamento) da carta de amigo da primeira metade do século XIX:

[...] Arnaldo! Abusei de ti, | E só agora é que eu vi, | Eu não tinha este direito | Por isso peço perdão, | Eu tinha bôa intenção, | O que me faltou foi geito.... || Folgo muito em te mandar, | quando estou a terminar | Esta carta tão modesta, | (P'ra que não fiques zangado) | Um beijo muito apertado | E um grande abraço na testa. Caramurú (CA15)

Nessa mesma carta de teor poético, há um Post scriptum, o único que encontramos em todas as missivas analisadas:

(42) Post scriptum:[...]P.S.: Se eu que não sou poeta, | Não deixei a Lyra quieta, | Em missiva tão custosa, | Julgo ser de teu dever. | Se algum dia responder. | Não fazel-o nunca em prosa. (CA15)

Os modos tradicionais de dizer no peroratio ou conclusio encontrados nas cartas de amigo da segunda metade do século XX são:

(43) Expressões tradicionais de despedida e assinatura (fechamento) da carta de amigo da segunda metade do século XX:

a. [...]Receba, meu caro Gilberto, com Dona Madalena | os meus cumprimentos e de Maria da Penha | e o testemunho da minha afetuosa admiração.|| Jordão Emerenciano. (CA20)

b. [...]Termino com beijo e abraço | da amiga G. (CA21)

c. [...]Com um abraço forte, para Voce e os demais | amigos, Uchôa o general [ate], assigna-lhe, seu do coração. [espaço] Ascenso Ferreira. Obs: meu endereço é. [endereço] (CA18)

As expressões destacadas acima são da carta de amigo da segunda metade do século XX. Não diferente das outras cartas de amigo e de família dos séculos XIX e XX, possuem grande emotividade e seguem as regras interacionais da carta pessoal. É preciso deixarmos claro que essas regras são inconscientes, arquivadas na memória social através de textos já escritos e lidos, modos de dizer como em: (43a): "[...] o testemunho da minha afetuosa admiração". Mais uma vez, temos, em (43b) e (43c)), expressões que indicam uma comunicação próxima do face a face como em "Temino com um beijo e abraço[...]" e em "Com um abraço forte[...]", respectivamente.

Dando prosseguimento, as expressões tradicionais de despedida e assinatura na carta de família parecem indicar uma maior intimidade entre os interlocutores, sobretudo, devido ao frequente uso de assinar apenas o primeiro nome ou apenas o apelido do missivista, como em (44 I (a) e (c)) e (44 II):

(44) Expressões tradicionais de despedida e assinatura (fechamento) da carta de família da segunda metade do século $\mathrm{XX}$ : 


\section{REVISTA DA ABRALIN}

\section{Despedida entre irmãs:}

a. 1 abraço saudoso e| as menninas a | mana.|| Elvira. (CF13)

b. Recommendações a Dr. 1 Orlando. Abraço [nas]| meninas a João e a si da \| sua mana || Elvira Fragoso. (CF06)

c. Aceite de Emilia as mais verdadeiras | expressões de sentimento e dor pelo seo esta- |do, um abraço em todos seus filhinhos e | me escreva já. Sua irmã e amiga || Ardimilra (CF07)

\section{Despedida de filho(a) para os pais (mãe ou pai):}

a. com saudosos abraços meus e Doutor Antonio. Os beijinhos de [inint.] para | todos Vocês || Biluca. (CF30)

b. Aqui termino enviando para todos Vocês um apertadíssimo | abraço, e para Você um abraço especial do filho que | sempre a quiz muito bem, Breno. (CF54)

c. o filho que muito os quer bem $\|$ Breno (CF52)

d. Aqui fica o filho amigo que sempre os quiz muito bem, Breno (CF55)

Ademais, os exemplos de fechamento acima possuem expressões linguísticas recorrentes que indicam uma comunicação de proximidade entre os interlocutores, como: "Aqui fica", "apertadíssimo abraço", "Aqui termino". Na despedida dessas missivas, também há recomendações, sentimentos de empatia, dor, alegria, prazer, saudade que contribuem para a expressividade de emoções. Nesse mesmo viés, as expressões tradicionais de despedida e assinatura da segunda metade do século XX nas cartas de família estão presentes nas cartas mais longas e nas menores e ainda apresentam no fechamento desejos e lembranças aos familiares. Há também a presença de possessivos, adjetivos e advérbios intensificando a expressividade da missiva e expressões como "Finalizo esta carta", "Vou terminando por falta de assunto", que é mais uma marca da proximidade comunicativa.

As duas cartas da missivista B. que constam em nosso corpus, a remetente da missiva encerra a carta com a expressão "Por falta de assunto":

(45) Expressões tradicionais de despedida e assinatura (fechamento) da carta de família da segunda metade do século XX:

aqui eu vou terminando | Por falta de asuto deixando um abraço | Para madrinha A. madrinha B. | muita lembrança Para o P. e S. | um abraço Para o Senhor |A minha mulher manda muita lembrança | Para o senho e dona V. e as minhas | Tias que ela não conhece. || mãe manda um abraço Para o senhor | e V. e a dona Z. || Para S. || Embreve nois mandamos carta novamente | mande resposta Para nois | [fol. 2v] Tio eu Tenho serteza que Se eu | ganha de Veriado eu Vou logo | Em Pernambuco. || Aqui eu Termino com um forte | Abraço Para Todos || Assina-se B. (CF57)

Vale referirmos aqui que a expressão "por falta de assunto" é recorrente nas missivas em geral e parece ser um recurso com a finalidade de cumprir o retenue (não querer preocupar ou enfadar o interlocutor), regra tradicional de interação das cartas pessoais. 


\section{REVISTA DA ABRALIN}

\section{Conclusão}

Através da análise dos modos recorrentes de dizer nas cartas de amigo e de família do século XIX e XX, observamos a implicação emocional atuando na intimidade entre os interlocutores para o estabelecimento da amizade (CASTILHO DA COSTA, 2012). Assim, o uso de expressões recorrentes da carta pessoal se apresentou nos dois subgêneros da missiva e nos dois séculos. Além disso, verificamos que esse uso oscila de missivista para missivista e também depende de com quem se fala, do objetivo da carta e da assimetria ou simetria no relacionamento construído entre os correspondentes.

Nesse sentido, o estabelecimento da amizade tem papel fundamental entre o tempo de escrita e a espera de resposta; por isso, vimo-lo a todo o momento atuando desde a abertura ou saudação, na captação da benevolência, no desenvolvimento do texto, na despedida e, até, nas expressões que precedem a assinatura. Isso demonstra que é o estabelecimento da amizade (ou amicita), através de elementos linguísticos que envolvem o correspondente e o mantém em uma relação de intimidade, que atua na proximidade comunicativa nas cartas pessoais. A manutenção de relação de intimidade e de proximidade comunicativa é concretizada a partir do cumprimento da regra interacional tradicional em responder a carta recebida. Portanto, a resposta é esperada e, com isso, o missivista deseja não apenas ter sido lido, mas correspondido em todos os sentidos desta palavra.

Ademais, vale referirmos que, para trabalhos futuros, esperamos não só ampliar os corpora de Pernambuco (incluindo os subgêneros: cartas de amigo, cartas de família e cartas de amor), mas também replicar a nossa opção teórico-metodológica aos novos achados, a fim de mapearmos as marcas tradicionais de dizer e suas implicações no estabelecimentos das relações à distância e aproximadas através da carta pessoal, tendo sempre em mente como o gênero carta pessoal, ao longo do tempo, evoca e atualiza tradições na história do texto e da língua.

Sobre a história da língua, em particular, ampliar o universo das cartas pessoais será crucial para uma maior compreensão de fenômenos linguísticos que emergem de contextos espontâneos de uso da língua (sobretudo, quando observadas cartas em que relações mais simétricas são verificadas). Nesse sentido, essas cartas, ao lado de outros gêneros como as peças de teatro amplamente analisadas em estudos diacrônicos, servem como um excelente expediente na constituição de corpora significativos baseados em registros mais próximos da oralidade ao longo das épocas?

\footnotetext{
${ }^{7}$ Agradecemos ao parecerista ad hoc pelos apontamentos feitos relativos à contribuição do trabalho com as cartas pessoais para os estudos históricos da língua.
} 


\section{REVISTA DA ABRALIN}

\section{Agradecimentos}

Esta pesquisa foi financiada com uma bolsa de estudos pelo Conselho Nacional de Desenvolvimento Científico e Tecnológico (CNPq).

\section{REFERÊNCIAS}

ANDRADE; C. V. O.; GOMES, V. S. História do Português Brasileiro: Tradições discursivas do português brasileiro: constituição e mudança dos gêneros discursivos. São Paulo: Contexto, 2018.

BAKHTIN, M. Estética da criação verbal. Trad. Maria Ermantina Galvão G. Pereira. São Paulo: Martins Fontes, [1953] 2003.

BAZERMAN, C. Gêneros textuais, tipificação e interação. São Paulo: Cortez, 2006.

BROWN, R.; GILMAN, A.The pronouns of power and solidarity. In: SEBEOK, T. A. (Ed.). Style in Language. Cambridge: Massachusetts, The MIT Press, 1960. p. 253-276.

CASTILHO DA COSTA. A. Ação -Formulação -Tradição: A correspondência de Câmara Cascudo a Mário de Andrade de 1924 a1944, entre proximidade e distância comunicativa. In: MARTINS, M. A.; TAVARES, M. A (Org.). História do português Brasileiro no Rio Grande do Norte: análise linguística e textual da correspondência de Luís da Câmara Cascudo a Mário de Andrade-1924 a 1944. Natal: EDUFRN, 2012. p.145-181.

COSTA, E. C. C.; SILVA, C. R. T.; GOMES, V. S. Marcas da oralidade na carta pessoal: apontando traços de tradição no discurso. In: SINALGE, 4, 2017, Campina Grande. Anais do IV SINALGE, Campina Grande: Realize, 2017. v. 1. p. $1-12$.

GOMES, V. S.; LOPES, C. R. S. Formas tratamentais em cartas escritas em Pernambuco (1869-1969): Tradição Discursiva e Sociopragmática. Revista de Estudos da Linguagem (RELIN), v. 24, n. 1, p. 157-189, 2016. DOI: http://dx.doi.org/10.17851/2237-2083.24.1.137-165

GUEDES, M.; BERLINK, R. A (Eds.). E os preços eram commodos: anúncios de jornais brasileiros século XIX. São Paulo: Humanitas, 2000.

KABATEK, J. Os falantes como linguistas: tradición, innovación e interferencias en galego (español) actual. Galicia: Edicions xerais, 1996.

KABATEK, J. Tradiciones discursivas y cambio linguístico. In: CIAPUSCIO, G.; KONSTANZE, J.; K., D..; LOPES, C. R. S. (Eds.). Sincronía y Diacronía de Tradiciones discursivas en Latinoamérica. Frankfurt a.m.: Vervuert, 2006. p. 151171.

KOCH, P.; OESTERREICHER, W. Oralidad y escrituralidad a luz de la Teoria del Lenguage. In: KOCH, P.; OESTERREICHER, W. Lengua Hablada en La Romania: español, francés, italiano. Madrid: Editorial Gredos. 2006. p. $20-42$.

LAKATOS, E. M.; MARCONI, M. A. Métodos científicos. In: LAKATOS, E. M.; MARCONI, M.A. Fundamentos de metodologia científica. São Paulo: Atlas, 2013. p. 83-113. 


\section{REVISTA DA ABRALIN}

LONGHIN-THOMAZI, S. R. Tradições Discursivas: conceito, história e aquisição. São Paulo: Cortez, 2014.

MARCUSCHI, L. A. Produção textual, análise de gêneros e compreensão. São Paulo: Parábola Editorial, 2008.

PESSOA, M. B. Latim II: Cartas de Cícero. Trad. Marlos de Barros Pessoa. Recife: UFPE, 2018.

PESSOA, M. B. Da carta a outros gêneros textuais. In: DUARTE, M. E. L.; CALLOU, D (Org.). Para a história do português brasileiro. Rio de Janeiro: UFRJ/LETRASFAPERJ, 2002. p. 198-205.

SCHRONDER, B. Bildung und Briefeim 6. Jahrhundert. Berlin: de Gruynter, 2007.

SILVA, A. G. Os subgêneros da carta pessoal em correspondências pernambucanas do século XX. 145f. Dissertação (Mestrado Linguística). PPGL/UFPE, Universidade Federal de Pernambuco, Recife, 2018.

SOUZA, J. P. F. Mapeando a entrada do você no quadro pronominal: análise de cartas familiares dos séculos XIXXX. 148f. Dissertação (Mestrado em Linguística). PGLV/UFRJ, Universidade Federal do Rio de Janeiro, Rio de Janeiro, 2012. 